\title{
KAJIAN STRUKTUR ARANG-PIROLISIS, ARANG-HIDRO DAN KARBON AKTIF DARI KAYU Acacia mangium Willd. MENGGUNAKAN DIFRAKSI SINAR-X ${ }^{*}$ \\ (X-Ray D iffraction O bservation of Pyrolized-Char, H ydro-Char and Activated Carbon Made of Acacia mangium Willd. Wood)
}

\author{
Saptadi Darmawan ", Wasrin Syafii' ${ }^{2}$, Nyoman J Wistara ${ }^{2}$, Akhirudin Maddu', \\ \& Gustan Pari ${ }^{4)}$ \\ ${ }^{1)}$ Mahasiswa Pascasarjana (S-3) Fakultas Kehutanan, Institut Pertanian Bogor \\ ${ }^{2)}$ D epartemen Teknologi Hasil Hutan, Fakultas Kehutanan, Institut Pertanian Bogor \\ ${ }^{3)}$ D epartemen Fisika, Institut Pertanian Bogor \\ ${ }^{4}$ Pusat Penelitian dan Pengembangan Hasil Hutan, Bogor \\ e-mail: saptadi_darma@yahoo.com \\ Diterima 25 Februari 2014, D isetujui 6 Maret 2015
}

\begin{abstract}
ABST RACT
Adivatedcarbonhasbeen used widdy for variausapplications Hydrodhar whichishydrothemally carbonizedfrom biomass caild be used as an altemative preeursor for adivated carbon manufacture, which is commonly dotained from pyrdized-dhar. Thispaperdbsevescrystallinestructureof A cadamangiumspyrdizedthar andhydrodhar usingXRD (X-raydiffradion). Themangumuoodvascarbonizedin $200^{\circ} \mathrm{Cand} 300^{\circ} \mathrm{C}$ anddepthanalysisvascondurtedbesedon adivated carbon product. Result shous carbon maturity index and arcmatidity fromboth prearsars (conventional and

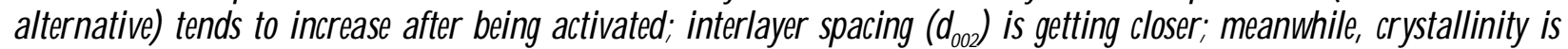
greater, and thenumber, height as wel as width of aromaticlayes areinmeasing Hydrodhar exhibited oystallinity degee maturityandaromatiatylower than thoseof thepyrdized-har ddainedat $300^{\circ} \mathrm{C}$ carbonization, with thegreater vdatilecontent. Bdh types of dar peformcarbon structure with ammphous texture Thegreatest iodineadsontion is

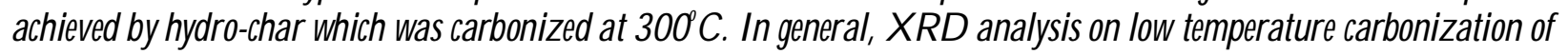
pyrdized-charandhydrodharcaildpredidtheporosityof adivatedcarbon
\end{abstract}

Keynards Adivatedcarbon, pyrdized-dhar, hydrodhar, XRD analysis mangimmood

\begin{abstract}
ABST RAK
"Kegunaan karbon aktif sangat luas dan penting untuk beragam aplikasi. Arang-hidro dari biomassa yang dibuat melalui proses karbonisasi hidrotermal merupakan prekursor alternatif terhadap prekursor konvensional untuk pembuatan karbon aktif yang selama ini banyak menggunakan arang dari proses pirolisis (prekursor konvensional). Tulisan ini menganalisa struktur kristalin arang-pirolisis dan aranghidro suhu $200^{\circ} \mathrm{C}$ dan $300^{\circ} \mathrm{C}$ serta produk karbon aktif menggunakan difraksi sinar-X (XRD). Hasil penelitian menunjukkan bahwa indeks kematangan dan tingkat aromatisasi karbon dari prekursor (baik konvensional atau alternatif) meningkat setelah diaktivasi; jarak antar lapisan gaphene $\left(\mathrm{d}_{002}\right)$ semakin kecil; sementara itu derajat kristalinitas, jumlah, tinggi dan lebar lapisan aromatik semakin besar. Arang-hidro memiliki derajat kristalinitas, indeks kematangan dan tingkat aromatisasi lebih rendah dari arangpirolisis suhu $300^{\circ} \mathrm{C}$ dengan kandungan bahan mudah menguap lebih tinggi. Keduanya telah
\end{abstract}

${ }^{*}$ Naskah merupakan bagian dari disertasi mahasiswa Program D oktor (S-3) pada Fakultas Kehutanan, Institut Pertanian Bogor 
membentuk struktur karbon bersifat amorf. Karbon aktif dari arang-hidro suhu $300^{\circ} \mathrm{C}$ menghasilkan daya jerap iodin tertinggi. Analisis XRD terhadap arang-pirolisis dan arang-hidro suhu rendah dapat memprediksi porositas karbon aktif yang dihasilkan.

Katakunci: Karbon aktif, arang-pirolisis, arang-hidro, analisis X RD, kayu mangium

\section{PENDAHULUAN}

Pemanfaatan biomassa hutan selain untuk produk perkayuan juga terindikasi kuat prospektif dikembangkan sebagai material karbon terutama karbon aktif dengan porositas tinggi. Hal ini dilatarbelakangi dari sifat biomassa yang dapat diperbaharui dan meningkatnya pemanfaatan material karbon sebagai komponen utama dari beberapa produk unggulan strategis. Kayu mangium (AcadamangumWilld.) merupakan jenis potensial yang banyak dikembangkan pada hutan tanaman industri(HTI).

Proses aktivasi untuk mendapatkan karbon aktif dari biomassa dilakukan terhadap arang sebagai produk antara (prekursor). Arang umumnya diperoleh dari karbonisasi pirolisis (KP) suhu $350^{\circ}-500^{\circ} \mathrm{C}$ (Chuenklang et al., 2002). Karbonisasi hidrotermal $(\mathrm{KH})$ dengan produk arang-hidro merupakan alternatif prekursor karbon aktif. Proses KH berlangsung dalam reaktor tertutup menggunakan media air dan tekanan dari air teruapkan (autogmauos pressure) padasuhu rendah (Libra etal., 2011).

Karbon aktif dengan porositas dan luas permukaan tinggi dapat diperoleh melalui proses kimia menggunakan hidroksi alkali (Wang et al., 2011). Di antara hidroksi alkali yang ada ( $\mathrm{NaO} \mathrm{H}$, $\mathrm{LiOH}$ dan $\mathrm{KOH}), \mathrm{KOH}$ merupakan aktivator paling efektif yang banyak diteliti (D emiral et al. 2008; Raymundo-Pinero etal., 2005).

Perbedaan mekanisme antara KP dan $\mathrm{KH}$ tentunya akan menghasilkan produk karbonisasi dan aktivasi dengan sifat tertentu. Difraksi sinar-X merupakan metode dasar untuk mengetahui struktur karbon (Yoshizawa et al., 2002). Metode ini banyak digunakan dalam penentuan struktur kristalin bahan dengan kandungan karbon tinggi seperti batu bara (Manoj \& Kunjomana, 2012; Sonibare et al., 2010; Takagi et al., 2004) dan beberapa bahan yang menggunakan arang/ karbon (Peters, 2011).

Parameter yang dipelajari adalah derajat kristalinitas (cystalinity, X), jarak antar lapisan graphene(intelayer spaing $d_{602}$ ), tinggi lapisan aromatik (cystallitesizealongthecaxis, Ld), lebar lapisan aromatik (cystallitesizealongthelateral, La), jumlah lapisan graphene(arcmaticlayes in the stadkingstruc ture, N), tingkat aromatisasi (aromaticity, fa), indeks kematangan karbon (carbon maturity index, $\mathrm{I}_{2 d}\left(\mathrm{I}_{20}\right.$ ) (Manoj \& K unjomana, 2012; Sonibare et al., 2010; Takagi et al., 2004; Kercher \& Nagle, 2003).

Pada penelitian ini dilakukan analisis terhadap arang-pirolisis dan arang-hidro pada suhu karbonisasi $200^{\circ} \mathrm{C}$ dan $300^{\circ} \mathrm{C}$ serta karbon aktifnya. Perubahan struktur kayu menjadi produk karbonisasi dan aktivasi dipelajari untuk mengetahui hubungannya dengan porositas karbon aktif. Sebagai pendukung dilakukan juga analisis proksimat berupa penentuan kandungan bahan mudah menguap, kadar abu, karbon terikat, dan daya jerap iodin serta penetapan kandungan unsur karbon (C) menggunakan energydispersiveXrayspetroscopy $(\mathrm{EDX})$.

\section{BAHAN DAN METODE}

\section{A. Bahan}

Bahan baku kayu mangium (Acacia mangium Willd.) diperoleh dari hutan rakyat di Bogor, Jawa Barat. Bahan kimia yang digunakan di antaranya kalium hidroksida $(\mathrm{KOH})$, hidrogen klorida $(\mathrm{HCl})$, dan iodin.

Persiapan bahan baku dilakukan dengan memotong kayu mangium, kemudian dibuat serpih terlebih dahulu sebelum dicacah. Ukuran bahan yang dikarbonisasi adalah yang tertahan pada saringan 80 mesh.

\section{B. Karbonisasi}

Karbonisasi pirolisis (KP) dilakukan dalam reaktor pirolisis berukuran panjang $60 \mathrm{~cm}$ dan diameter $7 \mathrm{~cm}$ yang diletakkan secara horisontal dengan pemanas listrik. Karbonisasi dilakukan pada suhu $200^{\circ} \mathrm{C}$ dan $300^{\circ} \mathrm{C}$ secara terpisah selama 6 jam. 
Karbonisasi hidrotermal (KH) dilakukan menggunakan digester berukuran panjang $60 \mathrm{~cm}$ dan diameter $21,5 \mathrm{~cm}$ yang dilengkapi dengan pemanas listrik. Media yang digunakan adalah air sebanyak sepertiga dari volume digester. Jumlah bahan baku yang dikarbonisasi sebesar $15 \%$ dari volume air (b/v). Karbonisasi dilakukan pada suhu $200^{\circ} \mathrm{C}$ dan $300^{\circ} \mathrm{C}$ secara terpisah selama 6 jam. Arang-hidro yang diperoleh kemudian dicuci menggunakan air di atas saringan 100 mesh sampai tingkat keasaman $(\mathrm{pH})$ netral kemudian dikeringkan dalam oven pada suhu $103 \pm 2^{\circ} \mathrm{C}$ sampai beratnya konstan).

\section{Aktivasi}

Perangkat aktivasi menggunakan reaktor pirolisis seperti proses karbonisasi pirolisis dengan menambahkan perangkat penghasil dan penyalur uap air. Aktivasi dilakukan terhadap arang-pirolisis dan arang-hidro secara terpisah dari masing-masing suhu. Potasium hidroksida sebagai aktivator pada perbandingan $\mathrm{KOH}$ : arang-pirolisis atau arang-hidro masingmasing sebesar 1:3 (b/ b). Sebanyak $150 \mathrm{~g}$ (BKO) arang-pirolisis atau arang-hidro direndam dalam $650 \mathrm{~mL}$ akuades yang di dalamnya telah dilarutkan $\mathrm{KOH}$ sebanyak 50 g. Agar arang-pirolisis atau arang-hidro terbasahi dengan sempurna maka sesekali dilakukan pengadukan dan didiamkan selama 24 jam. Setelah itu arangpirolisis dan arang-hidro dikeringkan dalam oven pada suhu $60^{\circ} \mathrm{C}$ selama 24 jam, selanjutnya contoh uji tersebut dimasukkan ke dalam reaktor dan diaktivasi hingga mencapai suhu $800^{\circ} \mathrm{C}$. Pada saat suhu aktivasi telah tercapai, dialirkan uap air dan kondisi tersebut dipertahankan selama 30 menit.

Karbon aktif (KA) yang dihasilkan dari prekursor arang-pirolisis atau arang-hidro dicuci dengan larutan $\mathrm{HCl} 10 \%$ dan air panas untuk menghilangkan pengotor dan menetralkan $\mathrm{pH}$. Karbon aktif dari arang-pirolisis dan arang-hidro hasil pencucian kemudian dikeringkan dalam oven pada suhu $102 \pm 3^{\circ} \mathrm{C}$ sampai beratnya konstan.

\section{Karakterisasi}

Analisis proksimat berupa penentuan bahan mudah menguap, kadar abu dan kadar karbon terikat dilakukan terhadap kayu mangium, arang- pirolisis, arang-hidro, dan karbon aktif (dari arang-pirolisis dan arang-hidro), sedangkan daya jerap iodin dilakukan terhadap karbon aktif (dari arang-pirolisis dan arang-hidro) menggunakan metode sesuai Standar Nasional Indonesia 013730 (BSN, 1995).

Analisis struktur karbon dilakukan terhadap seluruh contoh uji dalam bentuk serbuk lolos saringan 100 mesh menggunakan perangkatX RD Shimadzu 7000. Kondisi yang digunakan di antaranya: sumber radiasi berupa tembaga $(\mathrm{Cu})$, energi $40 \mathrm{kV}$, arus $30 \mathrm{~mA}$, kecepatan pemindai $2^{\circ}$ menit, pencatatan data setiap $0,02^{\circ}$ dan sudut pemindaian antara $10^{\circ}-80^{\circ}$. Parameter yang ditetapkan adalah derajat kristalinitas (X), jarak antar lapisan karbon aromatik $\left(\mathrm{d}_{602}\right)$, tinggi lapisan aromatik (Ld, lebar lapisan aromatik (La), dan jumlah lapisan gaphene $(\mathrm{N})$ berdasarkan rumus Bragg dan Scherrer's (Kercher \& Nagle, 2003; Iguchi, 1997) sebagai berikut:

$$
\begin{array}{ll}
\mathrm{X}(\%) & \text { bagian kristalin/ (bagian kristalin+ } \\
& \text { bagian amorf) } \mathrm{x} 100 \% ; \\
\mathrm{d}_{002}(\mathrm{~nm}) & =\lambda / 2 \sin \theta ; \\
\mathrm{LC}_{(002)}(\mathrm{nm})= & \mathrm{K} \lambda / \cos \theta ; \\
\mathrm{La}_{(100)}(\mathrm{nm})= & \mathrm{K} \lambda / \cos \theta ; \text { dan } \\
\mathrm{N} & =\mathrm{Lc} / \mathrm{d} .
\end{array}
$$

D imana:

$\lambda=0,15406 \mathrm{~nm}$ (panjang gelombang radiasi $\mathrm{Cu}$;

$\beta=$ Lebar maksimum pada intensitas setengah tinggi (FWHM);

$\mathrm{K}=$ Konstanta, untuk Lc=0,89 dan $\mathrm{La}=1,9$;

$\theta=$ Sudut difraksi dalam radian (/ 180).

Parameter lain yang dapat diukur menurut (Manoj \& Kunjomana, 2012; Sonibare et al., 2010) adalah indeks kematangan dan tingkat aromatisasi karbon. Tingkat aromatisasi ditentukan berdasarkan perbandingan antara ikatan karbon alifatik dan ikatan cincin aromatik karbon berturut-turut dari luas areal pada sudut 2 di $20^{\circ}(\mathrm{A})$ dan $26^{\circ}\left(\mathrm{A}_{002}\right)$ dengan persamaan:

$$
\begin{aligned}
\text { Tingkataromatisasi (fa) } & =\mathrm{C}_{\mathrm{arl}}\left(\mathrm{C}_{\mathrm{ar}}+\mathrm{C}_{\mathrm{a}}\right) \\
& =\mathrm{A}_{002} /\left(\mathrm{A}_{002}+\mathrm{A}\right)
\end{aligned}
$$

Indeks kematangan karbon ditentukan berdasarkan intensitas puncak pada posisi 2 di $20^{\circ}$ $\left(I_{20}\right)$ dan $26^{\circ}\left(I_{26}\right)$ dengan persamaan :

Indeks kematangan karbon $=\mathrm{I}_{26} / \mathrm{I}_{20}$ 
Penetapan beberapa parameter tersebut dilakukan dengan bantuan perangkat lunak X RD 6000/ 7000 versi 5.21.

Perangkat scanning deetron microscope (SEM) EVO 50 yang dipasangkan dengan perangkat enegy dispersiveX-rayspetroscopy (ED X) digunakan untuk melihat morfologi dan menentukan kandungan karbon relatif (wt\%).

\section{HASIL DAN PEMBAHASAN}

\section{A. Arang-pirolisis dan Arang-hidro}

Struktur kristalin kayu (lignoselulosa) dicirikan oleh struktur selulosa karena hemiselulosa selain berderajat polimerisasi rendah, terdapat gugus metil dan karbonil, sedangkan lignin bersifat amorf. Selulosa disusun dari unit monomer -D Glukopiranosa dengan derajat polimerisasi tinggi berupa rantai lurus tidak bercabang; hemiselulosa disusun dari monomer glukopiranosa (heksosan) dan glukofuranosa (pentosan) dengan derajat polimerisasi rendah dan bercabang; dan lignin bersifat amorf disusun dari unit phenil propana bercabang. Keberadaan selulosa pada kayu dikenali dari analisis XRD berupa puncak pada sudut 2 di sekitar $16^{\circ}$ dan $22^{\circ}$ (Poletto et al., 2012), begitu pula halnya dengan kayu mangium (Gambar 1).

Struktur kayu berubah setelah dikarbonisasi suhu $200^{\circ} \mathrm{C}$ dan tampak jelas pada suhu $300^{\circ} \mathrm{C}$ (Gambar 1). Kandungan karbon terikat arangpirolisis dan arang-hidro meningkat dengan naiknya suhu karbonisasi sedangkan bahan mudah menguap turun (Tabel 1). Karbonisasi menyebabkan penataan unsur karbon membentuk karbon aromatik dan semakin intensif dengan naiknya suhu (Pari, 2011). D ekomposisi sebagian komponen kimia kayu mulai terjadi pada produk karbonisasi suhu $200^{\circ} \mathrm{C}$ (proses menjadi eksotermik). Hemiselulosa merupakan senyawa yang pertama kali mengalami perubahan karena struktur hemiselulosa bercabang dan amorf (John \& Thomas, 2008).

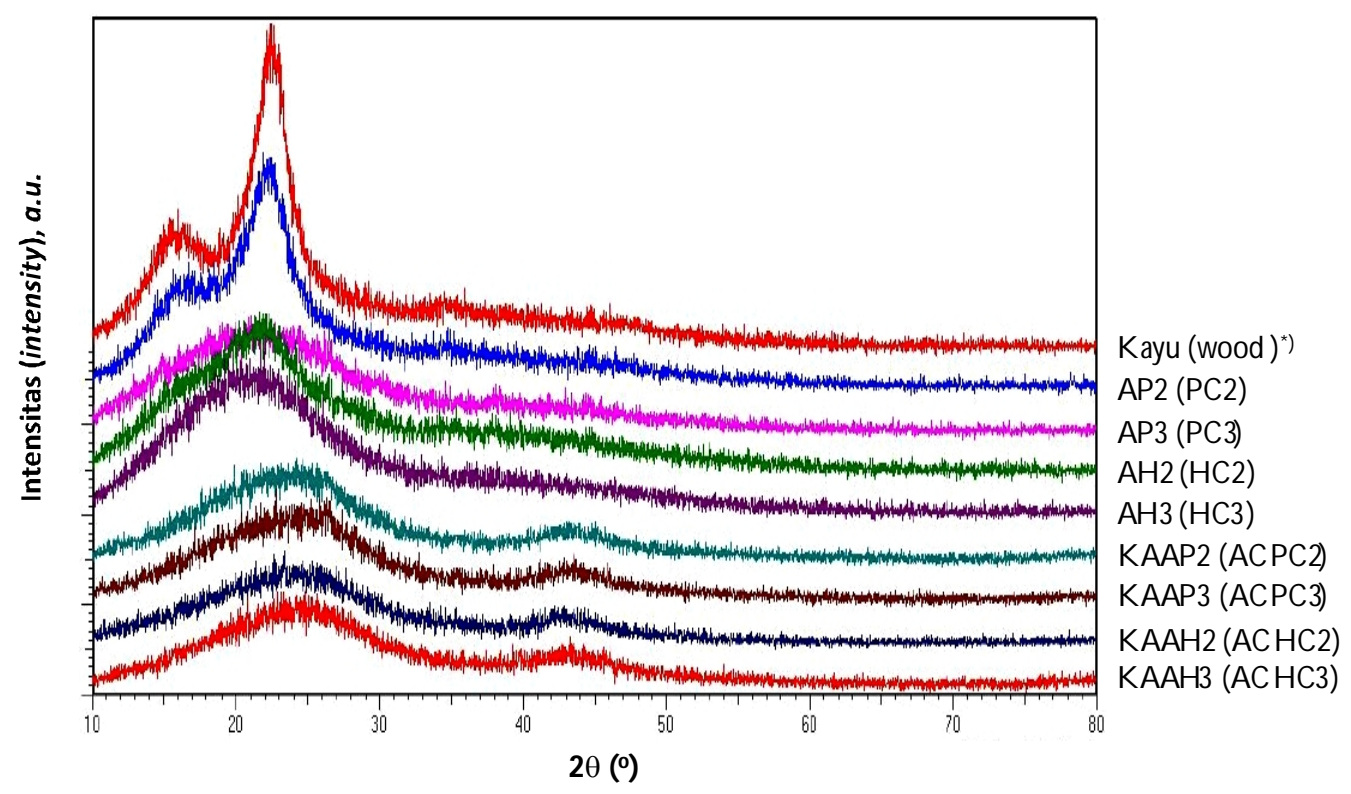

Gambar 1 Difraktogram kayu, arang-pirolisis, arang-hidro, dan karbon aktif Figure 1. D ifractograme of wood, pyrolized-char, hydro-char and acti vated carbon

\footnotetext{
${ }^{*}$ Untuk kode-kode tersebut, lihat keterangan pada Tabel 1 (For thecodes assum, peaserfertotheremarks Table1)
} 
Tabel 1. Analisis proksimat kayu, arang-pirolisis, arang-hidro, dan karbon aktif Table 1. Proximate analysis of wood, pyrolized-char, hydro-char and activated carbon

\begin{tabular}{|c|c|c|c|}
\hline \multirow{2}{*}{$\begin{array}{l}\text { Jenis contoh uji } \\
\text { (Typeof sample) }\end{array}$} & \multicolumn{3}{|c|}{ Analisis proksimat (Proximateanalysis), (\%) } \\
\hline & $\begin{array}{l}\text { Karbon terikat } \\
\text { (Fixed carbon) }\end{array}$ & $\begin{array}{l}\text { Zat menguap } \\
\text { (Vdatilematter) }\end{array}$ & $\begin{array}{l}\text { Abu } \\
\text { (Ash) }\end{array}$ \\
\hline K ayu (nood) & 17,47 & 82,01 & 0,52 \\
\hline \multicolumn{4}{|l|}{ Arang-pirolisis (Pyrdizetdhar) } \\
\hline - AP2 (PC2) & 24,07 & 75,43 & 0,50 \\
\hline - AP3 (PC3) & 64,61 & 34,67 & 0,72 \\
\hline \multicolumn{4}{|l|}{ Arang-hidro (Hydrodhar) } \\
\hline - AH2 (HC2) & 28,71 & 71,02 & 0,27 \\
\hline - AH3 (HC3) & 42,81 & 56,78 & 0,41 \\
\hline \multicolumn{4}{|l|}{ K arbon aktif (Adivatedcarban) } \\
\hline - KA AP2 (ACPC2) & 75,61 & 19,67 & 4,72 \\
\hline - KA AP3 (ACPC3) & 84,77 & 12,59 & 2,64 \\
\hline - KA AH2 (AC HC2) & 78,29 & 17,40 & 4,31 \\
\hline - КA АHЗ (АC HC3) & 82,37 & 15,39 & 2,42 \\
\hline
\end{tabular}

${ }^{\text {* }}$ Keterangan (Rerarks) :

$-\mathrm{AP2}(\mathrm{PC})=$ Arang-pirolisis pada suhu karbonisasi $200^{\circ} \mathrm{C}$ (Pyrdized-char thatresultedfrom200 Coubonization)

- AP3 (PC) = Arang-pirolisis pada suhu karbonisasi $300^{\circ} \mathrm{C}$ (Pyrdized-dharthatresulteelfirom300 2 Corbonization)

$-\mathrm{AH} 2(\mathrm{HC}) \quad=$ Arang-hidro pada suhu karbonisasi $200^{\circ} \mathrm{C}$ (Hydrodhar that resultedfrom2000 Carbonization)

$-\mathrm{AH} 3(\mathrm{HC})=$ Arang-hidro pada suhu karbonisasi $300^{\circ} \mathrm{C}$ (Hydrodhar thatresultedfrom300 $\mathrm{C}$ carbonization)

- KA AP2 (ACPC) = Karbon aktif dari arang-pirolisis pada suhu karbonisasi $200^{\circ} \mathrm{C}$ (Adivated carbonfrom pyrdized-dharat $200^{\circ}$ Carbonization)

- $\mathrm{KA} \mathrm{AP2} \mathrm{(ACPC)} \mathrm{=} \mathrm{Karbon} \mathrm{aktif} \mathrm{dari} \mathrm{arang-pirolisis} \mathrm{pada} \mathrm{suhu} \mathrm{karbonisasi} 300^{\circ} \mathrm{C}$ (Adivatedcarbonfrompyndized-dharat $300^{\circ}$ C carbonization)

- $\mathrm{KA} \mathrm{AH3}(\mathrm{ACHC})=\mathrm{K}$ arbon aktif dari arang-hidro pada suhu karbonisasi $200^{\circ} \mathrm{C}$ (Adivated carbonfromhydrodharat2000 $\mathrm{C}$ carbonization)

- $\mathrm{KA} \mathrm{AH3}(\mathrm{ACHC})=$ Karbon aktif dari arang-hidro pada suhu karbonisasi $300^{\circ} \mathrm{C}$ (Adivatedcarbonfromhydrodharat $300^{\circ} \mathrm{C}$ carbonization)

Reaksi utama pada karbonisasi pirolisis (KP) suhu $200^{\circ} \mathrm{C}$ adalah dehidrasi (Poletto et al., 2012) dan dekomposisi sebagian hemiselulosa melepaskan gas $\mathrm{CO}$ dan $\mathrm{CO}_{2}$ (Lv et al., 2010). Pada suhu $300^{\circ} \mathrm{C}$, dekomposisi hemiselulosa lebih intensif (Peters, 2011) dan mencapai titik tertinggi pada suhu $260^{\circ} \mathrm{C}$ (Lv et al., 2010). Pada suhu $300^{\circ} \mathrm{C}$, dekomposisi selulosa juga mulai berlangsung. Proses ini menyebabkan berkurangnya bahan mudah menguap dan terjadi penataan unsur karbon dengan meningkatnya karbon terikat dan tingkat aromatisasi.

Karbonisasi pirolisis (KP) dan karbonisasi hidrotermal $(\mathrm{KH})$ menghasilkan arang-pirolisis dan arang-hidro dengan sifat berbeda. Kandungan karbon terikat arang-pirolisis suhu $200^{\circ} \mathrm{C}$ lebih rendah dan bahan menguap lebih tinggi dibandingkan arang-hidro pada suhu yang sama (Tabel 1). Selulosa pada KP suhu $200^{\circ} \mathrm{C}$ belum sempurna terdekomposisi, yang terjadi adalah penurunan derajat polimerisasi melalui proses dehidrasi. Kondisi ini menyebabkan derajat kristalinitas arang-pirolisis suhu $200^{\circ} \mathrm{C}$ lebih rendah dari pada kayu dan lebih tinggi dari pada arang-pirolisis suhu $300^{\circ} \mathrm{C}$ (Tabel 3) karena terdapatnya selulosa pada arang-pirolisis $200^{\circ} \mathrm{C}$. Sementara itu KP suhu $300^{\circ} \mathrm{C}$, dekomposisi selulosa lebih besar yang dapat dilihat dari runtuhnya puncak selulosa (G ambar 1 ).

Intensitas arang-hidro suhu $200^{\circ} \mathrm{C}$ menunjukkan penurunan puncak lebih besar dibandingkan dengan arang-pirolisis pada suhu karbonisasi yang sama. Hal ini menunjukkan bahwa karbonisasi hidrotermal $(\mathrm{KH})$ berlangsung lebih intensif dibandingkan dengan karbonisasi pirolisis (Gambar1). 
Reaksi pada karbonisasi hidrotermal dipercepat oleh tekanan uap yang terbentuk (autogenous pressure) akibat pemanasan dalam reaktor tertutup. Dekomposisi lignoselulosa pada $\mathrm{KH}$ berlangsung pada suhu lebih rendah (Funke \& Ziegler, 2010; Libra et al., 2011) dibandingkan pirolisis karena perbedaan mekanisme antara KP dan KH. Pada karbonisasi hidrotermal selulosa, hemiselulosa dan lignin mulai terdekomposisi berturut-turut pada suhu $220^{\circ} \mathrm{C}$, $180^{\circ} \mathrm{C}$ dan $180^{\circ} \mathrm{C}$ (Bobleter, 1994). Hidrolisis kayu pada KH menghasilkan glukosa, selobiosa dan seloheksosa yang kemudian terdehidrasi dan terfragmentasi menjadi furan sebagai perantara (intermedate) pembentukan aromatik karbon melalui proses kondensasi dan dehidrasi (Ryu et al., 2010, Sevilla \& Fuertes, 2009; Titirici et al., 2008).

Selama proses karbonisasi hidrotermal, tekanan uap dan media air dalam reaktor membantu pembentukan pori. Hemiselulosa terhidrolisis dan terpisah dari lignin, sehingga arang-hidro memiliki kandungan oksigen tinggi dan tekstur lebih porous dibandingkan arangpirolisis (Hu et al., 2008; Schneider et al., 2011). Pada kondisi ini mikropori terbentuk walaupun dalam jumlah sangat kecil. Fenomena ini menunjukkan bahwa $\mathrm{KH}$ merupakan tahap awal dalam membentuk karbon aktif dengan porositas tinggi.

Karbonisasi pirolisis dan hidrotermal pada suhu $300^{\circ} \mathrm{C}$ menyebabkan dekomposisi selulosa berlangsung lebih intensif. Arang-pirolisis dan arang-hidro pada suhu karbonisasi $300^{\circ} \mathrm{C}$ telah mengalami perubahan struktur. Struktur awal berupa selulosa (kayu) menjadi struktur karbon bersifat amorf yang ditunjukkan dari perubahan puncak pada sudut 2 di sekitar 10-30' (Tabel 2 dan Gambar 1). Pada suhu ini mulai terjadi penataan unsur karbon dengan kandungan karbon terikat lebih tinggi dibandingkan kayu dan produk karbonisasi suhu $200^{\circ} \mathrm{C}$.

Tabel. 2. Kristalinitas, indeks kematangan dan tingkat aromatisasi karbon; kandungan karbon (EDX) dan daya jerap iodin dari produk karbonisasi dan aktivasi

Table2. Crystalinity, maturity index and aromaticity of carbon; carbon content (EDX), and iodineadsorption of carbonization and activation products

\begin{tabular}{|c|c|c|c|c|c|}
\hline $\begin{array}{l}\text { Jenis contoh uji } \\
\text { (Typeof sample)") }\end{array}$ & $\begin{array}{c}\text { Kristalinitas } \\
\text { (Crystalinity, X) } \\
(\%)\end{array}$ & $\begin{array}{c}\text { Indeks } \\
\text { kematangan } \\
\text { (Matunityindex, } \\
\left.\mathrm{I}_{26} \mathrm{I}_{20}\right)\end{array}$ & $\begin{array}{c}\text { Tingkat } \\
\text { aromatisasi } \\
\text { (Aromatiaty, fa) } \\
(\%)\end{array}$ & $\begin{array}{c}\text { Kandungan } \\
\text { karbon } \\
\text { (Carbon } \\
\text { content) } \\
(\%)\end{array}$ & $\begin{array}{c}\text { D aya jerap iodin } \\
\text { (Iodimeadsorption) } \\
(\mathrm{mg} / \mathrm{g})\end{array}$ \\
\hline Kayu (nood) & 44,10 & - & - & & - \\
\hline \multicolumn{6}{|c|}{ Arang-pirolisis (Pyrdizeddhar) } \\
\hline - AP2 (PC2) & 32,92 & - & - & 47,31 & - \\
\hline - AP3 (PC3) & 21,69 & 0,60 & 0,35 & 54,92 & - \\
\hline \multicolumn{6}{|l|}{ Arang-hidro (Hydrodhar) } \\
\hline - AH2 (HC2) & 22,44 & - & - & 53,30 & - \\
\hline - AH3 (HC3) & 20,34 & 0,33 & 0,26 & 54,09 & - \\
\hline \multicolumn{6}{|c|}{ Karbon aktif (Adivated carbon) } \\
\hline - KA AP2 (ACPC2) & 27,74 & 1,29 & 0,51 & 82,64 & 887,61 \\
\hline - KA AP3 (ACPC3) & 25,90 & 2,18 & 0,68 & 86,42 & 961,25 \\
\hline - KA AH2 (ACHC2) & 26,19 & 1,75 & 0,63 & 79,85 & 946,78 \\
\hline - KA AH3 (AC HC3) & 23,74 & 2,57 & 0,72 & 85,24 & 1036,01 \\
\hline
\end{tabular}

${ }^{*}$ Keterangan (Remarks) : Untuk kode-kodejenis contoh uji, lihat keterangan pada Tabel 1 (Forthetypeof samplecodes pleasenfer totheremarksTable1) 
Tabel 3. Analisis XRD pada kayu, arang-pirolisis, arang-hidro dan karbon aktif Table 3. XRD analysis of wood, pyrolized-char, hydro-char, and activated carbon

\begin{tabular}{lccccccc}
\hline \multicolumn{1}{c}{$\begin{array}{c}\text { Jenis contoh uji } \\
\text { (Typedf sample) }\end{array}$} & $\begin{array}{c}2 \theta \\
\left(\mathrm{d}_{002}\right)\end{array}$ & $\begin{array}{c}\mathrm{d}_{002} \\
(\mathrm{~nm})\end{array}$ & $\begin{array}{c}\mathrm{LC} \\
(\mathrm{nm})\end{array}$ & $\mathrm{N}$ & $\begin{array}{c}2 \theta \\
\left(\mathrm{d}_{100}\right)\end{array}$ & $\begin{array}{c}\mathrm{d}_{100} \\
(\mathrm{~nm})\end{array}$ & $\begin{array}{c}\text { La } \\
(\mathrm{nm})\end{array}$ \\
\hline K ayu (Wod) & - & - & - & - & - & - & - \\
\hline Arang-pirolisis (Pyrdizedthar) & & & & & & & \\
- AP2 (PC2) & - & - & - & - & - & - & - \\
- AP3 (PC3) & 21,22 & 0,4183 & 1,2806 & 3,06 & - & - & - \\
\hline Arang-hidro (Hydrodar) & & & & & & & \\
- AH2 (HC2) & - & - & - & - & - & - & - \\
- AH3 (HC3) & 21,97 & 0,4041 & 1,4886 & 3,68 & - & - & - \\
\hline K arbon aktif (Adivatedcarban) & & & & & & & \\
- KA AP2 (ACPC2) & 24,21 & 0,3673 & 1,4512 & 3,95 & 42,94 & 0,2104 & 8,1441 \\
- KA AP3 (AC PC3) & 24,43 & 0,3639 & 1,4600 & 4,01 & 43,45 & 0,2081 & 8,2960 \\
- KA AH2 (AC HC2) & 24,22 & 0,3671 & 1,4593 & 3,98 & 42,81 & 0,2110 & 9,3019 \\
- KA AH3 (AC HC3) & 24,45 & 0,3637 & 1,5308 & 4,21 & 42,87 & 0,2107 & 9,6834 \\
\hline
\end{tabular}

${ }^{*}$ Keterangan (Remarks) : Untuk kode-kode jenis contoh uji, lihat keterangan pada Tabel 1 (Forthetypesamplecodes pleaserfer totherenrarksTable1)

Struktur arang-pirolisis dan arang-hidro pada suhu $300^{\circ} \mathrm{C}$ menunjukkan perbedaan. Aranghidro menata unsur karbon lebih lambat dengan indeks kematangan dan tingkat aromatisasi karbon rendah (Tabel 2) serta kandungan bahan mudah menguap lebih besar dari pada arangpirolisis suhu $300^{\circ} \mathrm{C}$. Karbon dengan bahan mudah menguap tinggi saat diaktivasi akan diperoleh karbon aktif dengan porositas lebih baik (D emiral et al., 2008). Pada KP terjadi pelepasan bahan mudah menguap menjadi produk gas dan bahan terkondensasi untuk menata struktur karbon aromatik sehingga kandungan bahan mudah menguap lebih kecil.

Indeks kematangan karbon $\left(\mathrm{I}_{26} / \mathrm{I}_{20}\right)$ dan tingkat aromatisasi (fa) dipengaruhi oleh suhu dan jenis karbonisasi (G ambar 3). Kedua parameter tersebut baik pada arang-pirolisis dan arang-hidro suhu $200^{\circ} \mathrm{C}$ sulit ditetapkan karena pengaruh dari puncak selulosa, dengan kata lain produk karbonisasi belum membentuk formasi material karbon (arang). Parameter $\mathrm{I}_{20} / \mathrm{I}_{20}$ dan fa dapat teridentifikasi pada suhu $300^{\circ} \mathrm{C}$ di mana struktur karbon mulai tertata dan terjadi peningkatan nilai $\mathrm{I}_{2 \sigma} / \mathrm{I}_{20}$ dan fa(Tabel 2) dengan indeks kematangan dan tingkat aromatisasi karbon rendah. Kondisi ini mempengaruhi tinggi dan jarak antara lapisan graphene(d-spaing namun belum mengindikasikan terjadinya grafitisasi (Tabel 3).

\section{B. Karbon Aktif}

Sifat karbon aktif dipengaruhi oleh jenis prekursor. Hasil analisis XRD menunjukkan perubahan pola difraksi prekursor setelah diaktivasi, di antaranya pergeseran puncak utama ke arah sudut 2 lebih besar mendekati puncak grafit $\left(26^{\circ}\right)$ dan muncul puncak baru di sekitar sudut $43^{\circ}$ (Gambar 1). Kedua puncak tersebut merupakan penciri grafit pada bidang datar (pannar, $L_{2}$ ) sedangkan di sudut 25-26 merupakan struktur kristal grafit pada bidang vertikal (C-axis, L). Pada karbon aktif, struktur kristal seperti halnya grafit pada sudut 2 di sekitar $26^{\circ}$ tidak tampak. D ifraktogram sinar-X berbentuk amorf dengan kurva melebar pada sudut $10^{\circ}-30^{\circ}$. Perpaduan dari kedua puncak ini $\left(10^{\circ}-30^{\circ}\right.$ dan sekitar $26^{\circ}$ ) mengindikasikan bahwa karbon aktif bersifat turbostatio(Sonibare et al., 2010).

Melalui aktivasi terjadi peningkatan kandungan karbon terikat dan penurunan bahan mudah menguap cukup besar sehingga indeks kematangan dan tingkat aromatisasi karbon meningkat (Tabel 1 dan 3). Pada kondisi ini komponen kimia kayu (lignoselulosa) telah 


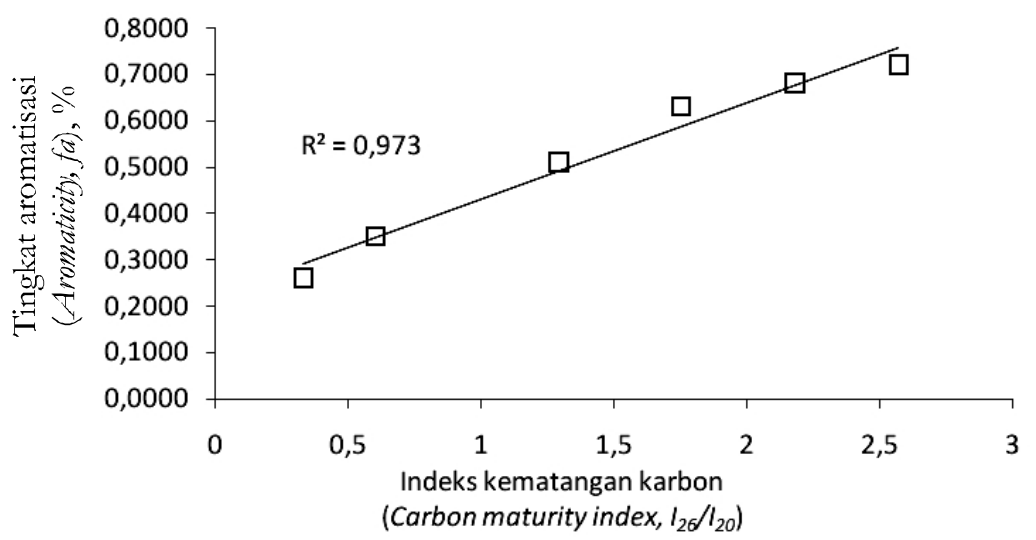

Gambar 2. Hubungan antara indeks kematangan $\left(I_{2 d} / I_{20}\right)$ dan tingkat aromatisasi karbon (fa) Figure 2. Relation between maturity index $\left(I_{26} / I_{20}\right)$ and aromaticity $(\mathrm{fa})$ of carbon

terdekomposisi dengan sempurna membentuk formasi karbon aromatik. Indeks kematangan $\left(\mathrm{I}_{2 \mathrm{~d}} \mathrm{I}_{20}\right)$ dan tingkat aromatisasi (fa) karbon mempunyai hubungan kuat yaitu semakin tinggi $\mathrm{I}_{2 d} \mathrm{I}_{20}$ maka nilai fa bertambah dengan nilai $\mathrm{R}^{2}$ sebesar 0,9735 (G ambar2).

Grafik pada Gambar 3 menunjukkan jarak antar lapisan gaphene $\left(\mathrm{d}_{02}\right)$ yang semakin menyempit dengan meningkatnya indeks kematangan dan tingkat aromatisasi karbon, sementara itu jumlah lapisan gaphenecenderung bertambah.

Kenaikan suhu pada proses karbonisasi dan aktivasi menyebabkan terjadinya penataan unsur karbon yang lebih intensif. Penyusunan karbon aromatik pada bidang aksial dan berkurangnya alifatik jenuh sebagai gugus fungsi pada karbon aromatik (Schoening, 1983) sejalan dengan berkurangnya bahan mudah menguap. Indeks kematangan dan tingkat aromatisasi prekursor suhu $200^{\circ} \mathrm{C}$ sulit ditentukan karena masih mempertahankan struktur selulosa (arangpirolisis dan arang-hidro suhu $200^{\circ} \mathrm{C}$ ). Prekursor tersebut mengandung bahan mudah menguap tinggi, saat diaktivasi sebagian besar senyawa tersebut dilepaskan termasuk unsur karbon dalam bentuk gas sehingga penataan karbon aromatik pada bidang plannar (La) lebih rendah dari pada prekursor suhu $300^{\circ} \mathrm{C}$, sementara itu arangpirolisis dan arang-hidro suhu $300^{\circ} \mathrm{C}$ telah membentuk struktur karbon aromatik bersifat amorf. Pada saat aktivasi berlangsung, penataan karbon terjadi secara perlahan membentuk karbon aromatik. Karbon aktif yang dihasilkan mengandung karbon terikat tinggi dan bahan mudah menguap lebih kecil serta indeks kematangan dan tingkataromatisasi tinggi.

Kecenderungan tersebut terjadi juga pada tingkat aromatisasi. Hubungan indeks kematangan dan tingkat aromatisasi karbon terhadap jarak antar lapiran graphene lebih kuat dibandingkan terhadap perubahan tinggi lapisan graphene dengan nilai $\mathrm{R}^{2}$ lebih besar (Gambar3).

Porositas karbon aktif dipengaruhi oleh prekursor karbonisasi. Karbon aktif dari masingmasing prekursor (arang-pirolisis dan arang-hidro suhu $200^{\circ} \mathrm{C}$ ) menghasilkan daya jerap iodin lebih rendah dibandingkan karbon aktif dari prekursor suhu $300^{\circ} \mathrm{C}$ walaupun arang-pirolisis dan aranghidro suhu $200^{\circ} \mathrm{C}$ memiliki kandungan bahan mudah menguap besar (Tabel 1 dan Gambar 4). Fenomena ini menjelaskan bahwa terdapat faktor lain yang berperan dalam pembentukan porositas pada karbon selain pengaruh bahan mudah menguap.

Berdasarkan data XRD, faktor yang turut berperan dalam pembentukan porositas adalah tingkat derajat kristalinitas dan struktur kristalin prekursor. Arang-pirolisis dan arang-hidro pada suhu $200^{\circ} \mathrm{C}$ memiliki kristalinitas lebih tinggi dibandingkan arang-pirolisis dan arang-hidro suhu $300^{\circ} \mathrm{C}$, dan belum membentuk struktur kerangka karbon bersifat amorf (Tabel 2 dan $\mathrm{G}$ ambar 1). Pada saat diaktivasi, penataan karbon aromatik lebih sulit diperoleh dibandingkan prekursor suhu $300^{\circ} \mathrm{C}$. 

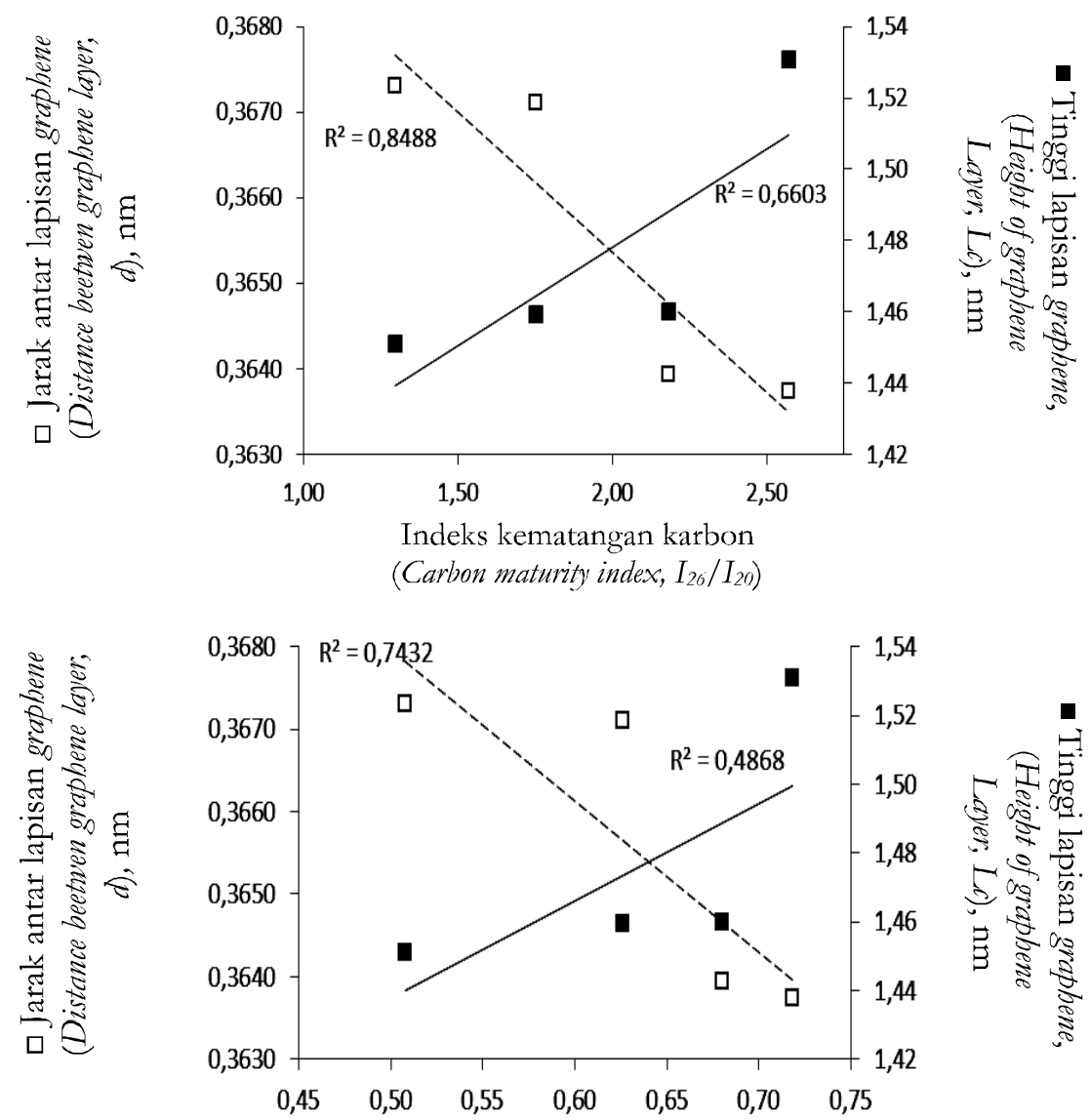

Tingkat aromatisasi (Aromaticity,fa), \%

Gambar3. Hubungan antara indeks kematangan dan tingkat aromatisasi karbon dengan tinggi dan jarak antarlapisan graphene

Figure3. Relation of carbon maturity index and aromaticity to height and to distance beetwen graphenelayer

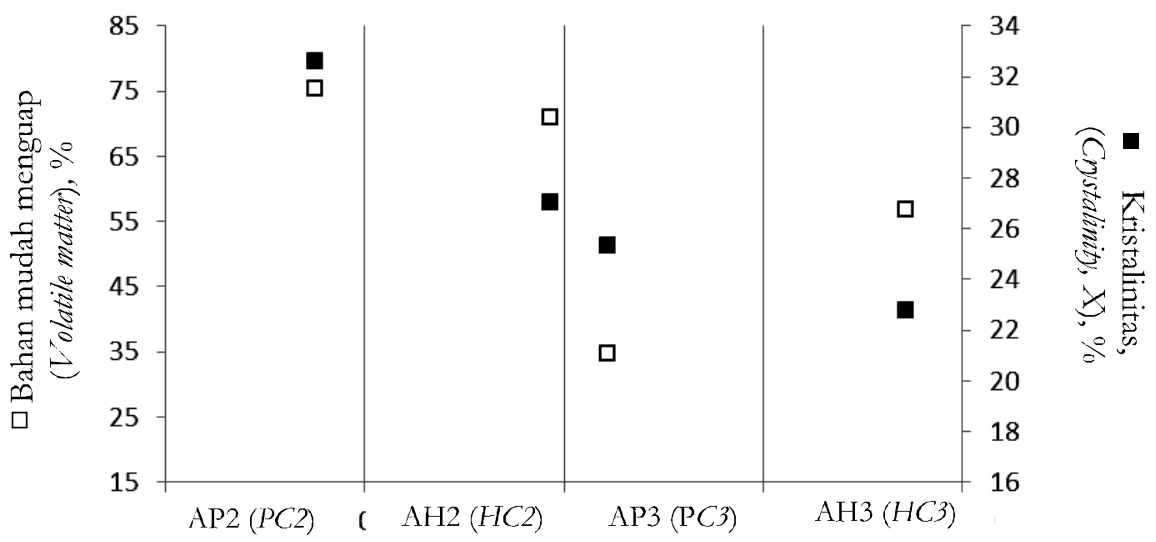

Daya jerap iod karbon aktif (Iodine adsorption of activated carbon), $\mathrm{mg} / \mathrm{g}$

Gambar4. Pengaruh bahan mudah menguap dan knistalinitas prekursor terhadap daya jerap iodin karbon aktif

Figure4. Effect of volatilesand crystallinity of the precursor on thei odi neadsorption of activated carbon 


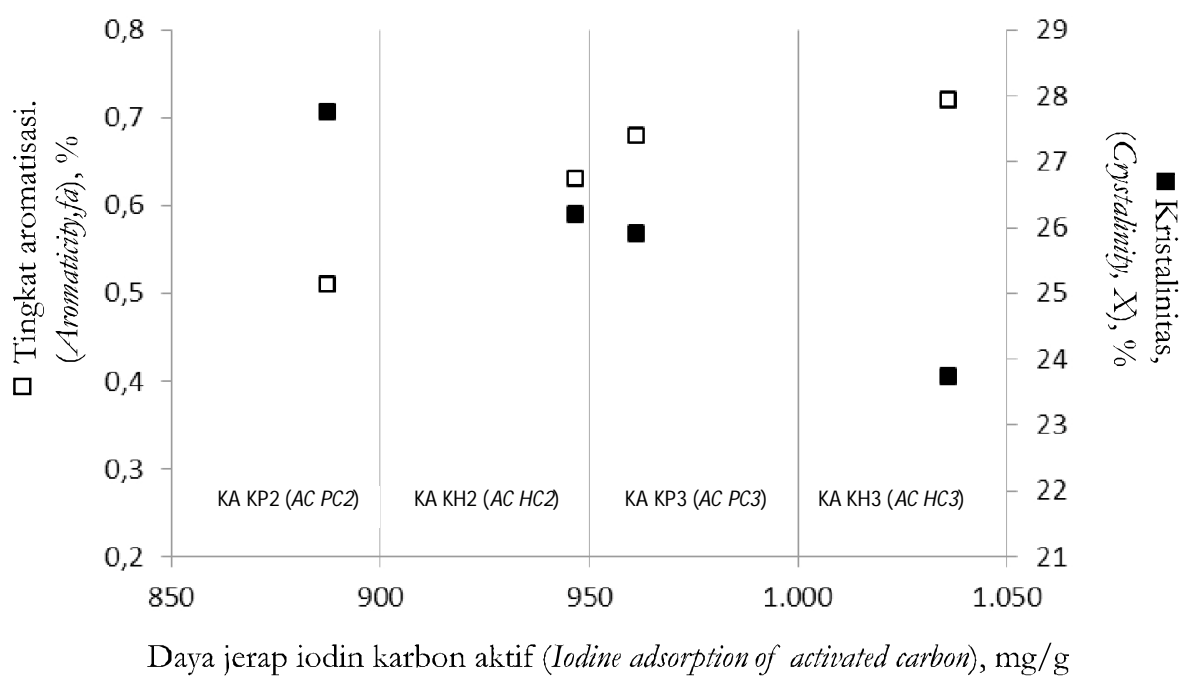

\section{Gambar5. Hubungan antara daya jerap iodin karbon aktif terhadap tingkat aromatisasi dan terhadap kristalinitas karbon aktif \\ Figure5. Relation of iodine adsorption of activated carbon to aromaticity and to crystalinity of acti vated carbon}

Arang-hidro suhu $300^{\circ} \mathrm{C}$ telah membentuk struktur karbon amorf dengan derajat kristalinitas rendah dan bahan mudah menguap tinggi. Saat aktivasi dilakukan terhadap arang-hidro, penataan aromatik karbon bersifat porous lebih mudah diperoleh dibandingkan arang-pirolisis suhu $200^{\circ} \mathrm{C}$, menghasilkan kristalinitas rendah dan tingkataromatisasi tinggi (G ambar 5).

\section{KESIMPULAN}

Karbonisasi kayu mangium pada suhu $200^{\circ} \mathrm{C}$ masih mempertahankan struktur kristalin selulosa di mana karbonisasi hidrotermal berlangsung lebih intensif mendekomposisi selulosa dibandingkan karbonisasi pirolisis. Karbonisasi suhu $300^{\circ} \mathrm{C}$ merupakan tahap awal perubahan struktur kayu (selulosa) mangium menjadi struktur karbon bersifat amorf dengan derajat kristalinitas dan bahan mudah menguap rendah serta unsur karbon tinggi. Pada suhu ini, kristalinitas arang-pirolisis dan kadar karbon terikat lebih tinggi serta zat menguap lebih rendah dari pada arang-hidro.

Karbon aktif telah terjadi penataan unsur karbon aromatik. Indeks kematangan dan tingkat aromatisasi meningkat dan memiliki korelasi positif yang kuat. Setelah diaktivasi jarak antar lapisan gaphene semakin menyempit, derajat kristalinitas meningkat, ukuran kristal (Ld) semakin tinggi dan telah membentuk struktur kristalin kearah mendatar(La).

Pada karbon aktif dari arang-pirolisis suhu $200^{\circ} \mathrm{C}$ memiliki kristalinitas lebih tinggi dari pada karbon aktif dari arang-hidro pada suhu yang sama, dengan kadar karbon terikat lebih rendah dan zat menguap lebih tinggi. Selanjutnya pada karbon aktif dari arang-pirolisis suhu $300^{\circ} \mathrm{C}$ memiliki kritalinitas lebih tinggi dibandingkan karbon aktif dari arang-hidro pada suhu yang sama, dengan kadar karbon terikatlebih tinggi dan zat menguap lebih rendah.

Dalam bentuk arang (arang-pirolisis atau arang-hidro) sifat yang dikehendaki sebagai prekursor pembuatan karbon aktif terutama adalah telah berubahnya struktur kristalin kayu/ selulosa menjadi karbon bersifat amorf yang memiliki kadar karbon terikat tinggi dan kristalinitas rendah. Sementara itu dalam bentuk karbon aktif sifat yang dikehendaki adalah kadar karbon terikat tinggi, porositas tinggi, indeks kematangan tinggi, tingkat aromatisasi tinggi, jarak antar lapisan gaphenedekat, dan ketinggian lapisan gaphenetinggi.

Penetapan sebagian parameter struktur kristalin karbon menggunakan XRD dapat dilakukan pada produk karbonisasi mangium suhu 
$300^{\circ} \mathrm{C}$ dan secara lengkap dapat dilakukan pada karbon aktif. Porositas karbon aktif dapat diperkirakan dari hasil analisis XRD terhadap arang-pirolisis dan arang-hidro suhu rendah.

\section{DAFTAR PUSTAKA}

Bobleter, O. (1994). Hydrothermal degradation of polymers derived from plants. Pdymer Säence, 19(5), 797-841.

Badan Standarisasi Nasional. [BSN]. (1995). Karbon Aktif. SNI 1-3730. Jakarta: Badan Standarisasi Nasional.

Chuenklang, P., Thungtong, S., \& Vitidsant, T. (2002). Effect of activation by alkaline solution on properties of activated carbon from rubber wood. Jaumal of Metals, MaterialsandMineals, 12(1), 29-38.

D emiral, H., Hakan, D., \& D emiral, I. (2008). Pore structure of activated carbon prepared from hazelnut bagasse by chemical activation. Surf. IntefaceAnal., 40, 616-619.

Funke, A., \& Ziegler, F. (2010). Hydrothermal carbonization of biomass: A summary and discussion of chemical mechanisms. Bicfuds Biqprod Biore, 4, 160-177.

Hu, B., Yu, S.H., Wang, K., Liu, L., \& Xu, X.W. (2008). Functional carbonaceous materials from hydrothermal carbonization of biomass: an effective chemical process. DaltonTrans, 5414-5423.

Iguchi, M. (1997). Pradice of Pdymer X-ray Diffraction Bandung: Bandung Institute Technology.

John, M.J., \& Thomas, S. (2008). Biofibres and biocomposites. Carbohydrate Pdymes 343364.

Kercher, A.K., \& Nagle, D.C. (2003). Microstructural evolution during charcoal carbonization by $\mathrm{X}$-ray diffraction analysis. Carbon, 41, 15-27.

Libra, J.A., Ro, K.S., Kamman, C., Funke, A., Berge, N.D., Neubauer, Y., ... Kern, J. (2011). Hydrothermal carbonization of biomass residuals: a comparative review of the chemistry, processes and applications of wet and dry pyrolysis. Bifuds, 2(1), 89124.

Lv, G.J., Wu, S.B., \& Lou, R. (2010). Characteristics of corn stalk hemicellulose pyrolysis in a tubular reactor. BioResarces, 5(4), 2051-2062.

Manoj, B., \& Kunjomana, A. (2012). Study of stacking structure of amorphous carbon by $\mathrm{X}$-ray diffraction technique. Int. J. Eletrodhem Sa., 7, 3127-3134.

Pari, G. (2011). Pengaruh selulosa terhadap struktur karbon arang Bagian I - Pengaruh suhu karbonisasi. Jumal Penditian Hasil Hutan, 29(1), 33-45.

Peters, B. (2011). Prediction of pyrolysis of pistacho shells based on its components: hemicellulose, cellulose and lignin. Fud ProcessingTehndogy, 92(10), 1993-1998.

Pettersen, R.C. (1984). The chemical composition of wood. Dalam Rowell R. (Ed.), The Chemistry of Sdid Wood (pp. 57-126). Washington, D.C:ACS.

Poletto, M., Zattera, A.J., Forte, M., \& Santana, R. (2012). Thermal decomposition of wood: Influence of wood components and cellulose crystallite size. Bioresource Tehndogy, 109, 148-153.

Raymundo-Pinero, E., Azais, P., Cacciaguerra, T. \& Cazorla-Amoros, D. (2005). KOH and $\mathrm{NaOH}$ activation mechanisms of multiwalled carbon nanotubes with different structural organisation. Carbon, 43, 786-795.

Ryu, J., Suh, Y.W., Ahn, D.J., \& Suh, D.J. (2010). Hydrothermal preparation of carbon microspheres from mono-saccharides and phenolic compounds. Carbon, 48, 1990 . 1998.

Schneider, D., Escala, M., \& Supawitta, K. (2011). Characterization of biochar from hydrothermal carbonization of bamboo. International Energy \& Environment Foundation, 2(4), 647-652. 
Schoening, F.L. (1983). X-ray structure of some South African coals before and after heat treatment at 500 and $1000^{\circ} \mathrm{C}$. Fud, 62(11), 1315-1320.

Sevilla, M., \& Fuertes, A. (2009). The production of carbon materials by hydrothermal carbonization of cellulose. Carbon, 49, 2281-2289.

Sonibare, O.O., Haeger, T., \& Foley, S.O. (2010). Structural characterization of Nigerian coals by X-ray diffraction, Raman and FTIR spectroscopy. Enegy, 35, 5347-5353.

Takagi, H., Maruyama, K., Yoshizawa, N., Yamada, Y., \& Sato, Y. (2004).X RD analysis of carbon stacking structure in coal during heat treatment. Fud, 83(17), 2427-2433.
Titirici, M.M., Antonietti, M., \& Baccile, N. (2008). Hydrothermal carbon from biomass: a comparison of the local structure from poly- to monosaccharides and pentoses/ hexoses. Gren Chem, 10, 1204-1212.

Wang, L., Guo, Y., Zou, B., Rong, C., Ma, X., Qu, Y., ... Wang, Z. (2011). High surface area porous carbons prepared from hydrochars by phosphoric acid activation. Biaresarce Techndogy, 102(2), 1947-1950.

Yoshizawa, N., Maruyama, K., Yamada, Y., Ishikawa, E., Kobayashi, M., Toda, Y., \& Shiraishi, M. (2002). XRD evaluation of $\mathrm{KOH}$ activation process and influence of coal rank. Fud, 81(13), 1717-1722. 